\section{Wheatgrass Response to Seasonal Applications of Two Nitrogen Sources}

\section{FORREST A. SNEVA}

Highlight: Fall, winter, and spring applications of $20 \mathrm{lb}$. N/acre as urea or as ammonium nitrate were applied in each of 3 years to two introduced grasses, crested and Siberian wheatgrasses, on Oregon's high desert range. Mature herbage yield increased with fertilizers, but there were no significant interactions with application date. Urea increased mean yield 3\% more than did ammonium nitrate, but the increase may not be of practical significance. Crude protein concentration of mature yields, evaluated in 1 year only, was not influenced by either fertilizer or application time. Fall-and winter-applied $N$ fertilizer increased available soil nitrate concentration in mid-A pril, but differences due to date and source of $N$ were nil.

Returns from nitrogen $(\mathrm{N})$ fertilizers applied to seeded grass stands on semiarid lands of the Great Basin and bordering areas have been marginal to submarginal (Sneva et al., 1958; Patterson and Youngman, 1960; Eckert, et al., 1961; Kay and Evans, 1965; and Sneva, 1970).

These returns, for the most part, have been based upon the vegetal response from fall applied ammonium nitrate. There is virtually no research information as to the efficiency of $\mathrm{N}$ as influenced by source of $\mathrm{N}$ or by its time of application for introduced grasses on semi-arid soils of the northern Great Basin. Monetary values to the rancher may also be influenced by time of application as it relates to (1) time of fertilizer purchase, (2) storage costs, and (3) seasonal workload (Lavin, 1967).

Response to $\mathrm{N}$ fertilizer in arid regions has been greatest in years receiving greater than normal amounts of precipitation (Sneva, 1965). Thus, selective fertilization for response in above normal years could enhance the economic picture. Unfortunately, with fall fertilization the judgement of the favorableness of the coming season is not feasible. Decision making for applying fertilizer in the spring could be much more effective. The

The author is range scientist, Plant Science Research Division, Agricultural Research Service, U. S. Department of Agriculture, Burns, Oregon.

The project was jointly operated by Oregon Agricultural Experiment Station and Plant Sci. Res. Div., Agr. Res. Serv., U. S. Dep. Agr., (Technical Paper No. 3355 Ore. Agr. Exp. Sta.)

Manuscript received July 7, 1972. greater part of the precipitation would have been received, and only that remaining to be received in the subsequent 2-3 months need be estimated by predictions.

Because of technological advances in the past decade, urea is a strong competitor as the cheapest source of N. Comparisons of urea with ammonium nitrate are lacking for the semi-arid range area.

This paper compares mature yields in 3 years, available soil nitrogen in 2 years, and herbage concentrations of crude protein in 1 year as influenced by urea and ammonium nitrogen fertilizer applied in fall, winter, and spring.

\section{Procedure}

The study site is located within the Squaw Butte Experiment Station, 42 miles west of Burns, Ore. Annual precipitation at this $4,300 \mathrm{ft}$ elevation station is approximately 12 inches. Big sagebrushbunchgrass types dominated the areas now seeded to introduced species. The sandy-loam soils supporting these stands have been described by Eckert (1957).

The study was conducted with the 3 years $(1969,1970$, and 1971) and seven application dates (Sept. 15, Nov. 15, Jan. 15, Feb. 15, March 15, Apr. 15, and May 15) randomly allocated to main plots in factorial combinations. Main plots consisted of 6, 10-ft rows spaced $1 \mathrm{ft}$ apart. The two sources of $\mathrm{N}$ and a control were allocated to subplots, a single row each with a buffer row between each treatment row. Treatments were replicated four times in standard crested wheatgrass (Agropyron desertorum [Fisch,] Schult). and four times in Sibcrian wheatgrass (Agropyron sibiricum [Beauv.]) stands. The replications were $30 \times 60$-ft blocks seeded in 1957 and comprising a portion of a larger study (Hyder and Sneva, 1963). Fertilizer at the rate of $20 \mathrm{lb}$ $\mathrm{N} /$ acre was weighed, packaged, and, on the given date, applied by hand. The fertilizer was applied directly to the row; rarely did pellet dispersion exceed 3 inches on either side of the row center. Row ends were marked with 18-inch wire flags for determining row location when snow covered. When rows were snow covered, foot tracks directly above the row were made and fertilizer distributed within the track.

Herbage was clipped at ground level from the center $8 \mathrm{ft}$ of the treatment row on or about August 1 of 1969, 1970, and 1971. Following harvesting, the herbage was oven dried at $160 \mathrm{~F}$. Yield samples in 1969 were subsequently ground through a Wiley mill and a subsample retained for determining Kjeldahl-N. Yield and crude protein $(\mathrm{N} \times 6.25)$ values were statistically analyzed and differences between means tested with Duncan's multiple range test.

General observations of surface and subsurface soil conditions (0-6 inches) at the time of fertilizer applications were recorded. Precipitation, air, and soil temperature during the study years were rccorded daily at the Station's headquarters $1 / 2$ mile away.

Soil samples for determining available soil nitrate were taken on April 10,1969, and April 15, 1970. In 1969, soils were sampled at 0-3, 3-6, and 6-9 inches below the soil surface. Samples in 1970 were from the 0-3 inch depth. Each sample consisted of two, 1/2 inch diameter cores obtained directly from the row center of each plot between plants, from the first five application dates on four replications. The samples were air dried, thoroughly mixed, and two determinations per sample conducted with a LaMotte Available Soil Nitrate Kit ${ }^{1}$.

\section{Results}

Surface and subsurface soil moisture characteristics at the time of fertilizer application in each year, average maximum and minimum soil temperature at 2 inches, and mean air temperature in the week following are shown in Table 1 . Total crop-year precipitation (Sept. 1-June 30) was 10.7, 9.9, and 11.4 inches for the years 1969, 1970, and 1971, respectively.

Significant differences due to species interaction did not occur. Thus, the data were analyzed as that of one species with eight replications. The herbage will here-

\footnotetext{
$1_{\text {The mention of a proprietary product does }}$ not constitute a guarantee of the product by U. S. Dep. Agr., and does not imply its approval to the exclusion of other products that may also be suitable.
} 
Table 1. Soil moisture characteristics, soil temperature (F), and air temperature (F) at the time of fertilizer application.

\begin{tabular}{|c|c|c|c|c|c|}
\hline \multirow{2}{*}{$\begin{array}{c}\text { Date of } \\
\text { application }\end{array}$} & \multicolumn{2}{|c|}{ Moisture characteristics } & \multicolumn{2}{|c|}{ Soil temperature ${ }^{1}$} & \multirow{2}{*}{ Air temperature } \\
\hline & Surface & Subsurface & Max. & Min. & \\
\hline Sept. 24,1968 & Dry & Dry & 75 & 55 & 58 \\
\hline Nov. 15,1968 & $1 / 2$ in. snow & Moist & 41 & 41 & 33 \\
\hline Jan. 15,1969 & $1 / 2$ in. snow, frozen & Moist & 39 & 39 & 25 \\
\hline Feb. 17,1969 & 8 in. snow & Moist & 39 & 36 & 26 \\
\hline Mar. 14,1969 & 10 in. snow & Moist & 39 & 37 & - \\
\hline April 16, 1969 & Dry & Moist & 61 & 47 & 33 \\
\hline May 15,1969 & Dry & Moist & 71 & 54 & 53 \\
\hline Sept. 16, 1969 & Dry & Dry & 78 & 55 & 53 \\
\hline Oct. 19,1969 & Moist & Moist & 58 & 44 & 49 \\
\hline Jan. 15,1970 & 4 in. snow & Moist & 38 & 38 & 38 \\
\hline Feb. 1970 & Dry, unfrozen & Moist & 39 & 39 & 32 \\
\hline Mar. 17, 1970 & Moist & Moist & 52 & 41 & 35 \\
\hline April 15, 1970 & Dry & Moist & 58 & 41 & 36 \\
\hline May 17,1970 & Dry & Moist & 81 & 56 & 58 \\
\hline Sept. 25,1970 & Dry & Dry & 80 & 51 & 51 \\
\hline Nov. 20,1970 & Moist & Dry & 41 & 40 & 31 \\
\hline Jan. 18,1971 & Snow, free water & Moist & 39 & 39 & 33 \\
\hline Feb. 15,1971 & Damp & Moist & 39 & 39 & 33 \\
\hline Mar. 9,1971 & Dry & Moist & - & - & 31 \\
\hline April 14, 1971 & Damp & Moist & 58 & 45 & 40 \\
\hline May 17,1971 & Dry & Moist & 76 & 50 & 40 \\
\hline
\end{tabular}

${ }_{2}^{1}$ Mean values at 2 inches below soil surface for the week following application.

${ }^{2}$ Mean air temperature for the week following application.

after be referred to as crested wheatgrass.

Study yields differed significantly $(\mathrm{P}<$ 0.01 ) by years and averaged $100.2,73.4$, and $90.0 \mathrm{~g} /$ sample for 1969,1970 , and 1971 , respectively. Date of application was also a significant source of variation $(\mathrm{P}<0.05)$; but in the absence of any significant interaction, its importance relates to study variability.

Mean sample yields were $76.5,92.8$, and $95.4 \mathrm{~g}$, respectively, for no fertilizer, ammonium nitrate, and urea. These yields differed significantly $(P<0.01)$ from each other.

Crude protein concentrations in mature herbage harvested in 1969 did not differ from each other regardless of treatment or application date. The mean crude protein concentration was $4.2 \%$.

Average available soil nitrate, at three soil levels in the spring of 1969 and at one soil level in the spring of 1970, is tabulated in Table 2. In 1969, there was no available soil nitrate at any depth of sampling of any unfertilized plots. Fertilizers applied in the fall of 1958 and winter, 1969, increased concentrations of available soil nitrate at all sampled depths; but concentrations in the surface 3 inches were influenced the most.

Available soil nitrate in the surface 3 inches was in greater supply on both fertilized and unfertilized plots in spring, 1970 , than on the similar sampling date in 1969. Urea and ammonium nitrate both caused a significant increase $(\mathrm{P}<$ 0.05 ) in available soil nitrate above that of controls, but differences between the two fertilizers were not significant (P> 0.05 ).

\section{Discussion}

Herbage yield and $\mathrm{N}$ response in 1969 were probably influenced by carryover effects of 1968. A record drought in 1968 probably resulted in a more favorable soil $\mathrm{N}$ status in 1969 and consequently reduced response to applied $\mathrm{N}$. The drought was broken by abnormally high precipitation (2.75 inches) in August, which quite likely enhanced the effectiveness of the 1969 crop-year precipitation.

Mean $\mathrm{N}$ response by years was 28,12 ,
1 Observations were made on April 10, 1969.

2 Observations were made on April 15, 1970. and $38 \%$ for 1969,1970 , and 1971 , respectively, and was in direct relation with total crop-year precipitation received. Mature yields were increased 23\% with ammonium nitrate and $26 \%$ with urea fertilizer. The small response to $\mathrm{N}$ in this study is believed to have resulted from the manner in which the study was conducted. Although individual rows at $1-\mathrm{ft}$ spacings are quite discrete, it is unlikely that their root systems are. I believe that the adjacent buffer rows were obtaining some of the applied fertilizer through their root system; subsequently, less applied $\mathrm{N}$ was available for grasses in fertilized rows. This dilution effect may have reduced the opportunity to detect differences due to treatments.

The small differences between response to ammonium nitrate and urea, though significant, may not be of practical significance. The lack of strong differences between these two fertilizers in this study agrees with results on wild-flood meadows (Rumburg, 1961).

Bleak (1961) and Hull (1963) found spring applications of $\mathrm{N}$ no better than fall applications on grasses growing at high elevations. Equality of response to application in the fall, winter, and spring months in this study are in accord with their findings.

Nitrogen fertilization has often increased crude protein concentrations in herbage grown on semi-arid lands (Duncan and Hylton, 1970). However, in the majority of studies they reviewed, the rates of $\mathrm{N}$ used were substantially higher than in this study. Previous research at this Station suggests that 20 or $30 \mathrm{lb}$ $\mathrm{N} /$ acre would increase crude protein concentrations in dry years but not in normal or above-normal years (Sneva et

Table 2. Available soil nitrate (ppm) under crested wheatgrass at 0-3, 3-6, and 6-9 inches on April 10, 1969 and at 0-3 inches on April 15, 1970, as influenced by fertilizer treatment.

\begin{tabular}{|c|c|c|c|c|c|c|c|c|c|}
\hline \multirow{3}{*}{$\begin{array}{c}\text { Date } \\
\text { applied }\end{array}$} & \multicolumn{9}{|c|}{ Soil depth } \\
\hline & \multicolumn{3}{|c|}{$0-3$} & \multicolumn{3}{|c|}{$3-6$} & \multicolumn{3}{|c|}{$6-9$} \\
\hline & No Fert & $\mathrm{NH}_{4} \mathrm{NO}_{3}$ & Urea & No Fert. & $\mathrm{NH}_{4} \mathrm{NO}_{3}$ & Urea & No Fert. & $\mathrm{NH}_{4} \mathrm{NO}_{3}$ & Urea \\
\hline \multicolumn{10}{|l|}{1968} \\
\hline Sept. $24^{1}$ & 0 & 2 & 4 & 0 & 1 & 1 & 0 & 0 & 0 \\
\hline Nov. $15^{1}$ & 0 & 4 & 2 & 0 & 1 & 0 & 0 & 1 & 1 \\
\hline \multicolumn{10}{|l|}{1969} \\
\hline Jan. $15^{1}$ & 0 & 3 & 2 & 0 & 1 & 1 & 0 & 1 & 1 \\
\hline Feb. $17^{1}$ & 0 & 3 & 2 & 0 & 1 & 2 & 0 & 1 & 1 \\
\hline Mar. $14^{1}$ & 0 & 1 & 1 & 0 & 0 & 1 & 0 & 0 & 0 \\
\hline Sept. $16^{2}$ & 4 & 8 & 8 & - & - & - & - & - & - \\
\hline Oct. $19^{2}$ & 3 & 8 & 9 & - & - & - & - & - & - \\
\hline \multicolumn{10}{|l|}{1970} \\
\hline Jan. $15^{2}$ & 4 & 9 & 14 & - & - & - & - & - & - \\
\hline Feb. $16^{2}$ & 3 & 16 & 12 & - & - & - & - & - & - \\
\hline Mar. $17^{2}$ & 4 & 14 & 5 & - & - & - & - & - & - \\
\hline
\end{tabular}




\section{al., 1958; and Sneva, 1965).}

Fertilizers applied in the fall and winter months in 2 years increased available soil nitrate at all sampled levels; largest increases werc in the surface 3 inches. The greatest increase occurred in 1970 . Differences in growth activity of the grass, and hence the rapidity of removal of available $\mathrm{N}$, probably accounted for differences between the 2 years. Mean maximum temperature for the 5-day period prior to sampling was $52 \mathrm{~F}$ in 1969 , approximately $8 \mathrm{~F}$ warmer than that for a similar period in 1970 . Thus, growth in 1969, particularily on unfertilized plots on or about April 10, may have been utilizing all soil $\mathrm{N}$ available. This total use of mobilized soil $\mathrm{N}$ by growing grasses is not uncommon in grassland soils (Walker, 1956). Except for available soil nitrate data of March 14, 1969, the levels of available nitrate as influenced by the date of application also indicate agreement with the harvested yield data.

Fertilizers applied in early fall of 1970 were exposed to dry soil conditions as long as 4 weeks. In February and March, 1969 , application of $\mathrm{N}$ was on deep snow. Losses of $\mathrm{N}$ may occur through gaseous processes under these circumstances. Wullstein and Gilmour (1964) suggest that gaseous losses of $\mathrm{N}$ from surfaceapplied $\mathrm{N}$ fertilizers on rangelands may be of economic significance. If such losses took place in this trial and differed because of date of application, those differences were masked by other factors more dominant or similar for all dates.

\section{Conclusions}

Urea fertilizer was slightly more effective $(3 \%)$ than ammonium nitrate in increasing mature yield of crested wheatgrass. No difference in mature yield increase was found among fertilizer applications made in the fall, winter, or spring. Thus, fertilizer purchase time relative to market prices, storage opportunity and cost, and application time relative to seasonal workload can be important considerations when figuring the economics of $\mathrm{N}$ fertilization of crested wheatgrass on eastern Oregon rangelands.

\section{Literature Cited}

Bleak, A. T. 1961. Range fertilization studies for central Utah. Agr. Res. Serv., U. S. Dep. $\Lambda$ gr., Range Fertilization Workshop, Denver, Colo. Mimeo $4 \mathrm{p}$.

Duncan, Don A., and Lynn O. Hylton, Jr. 1970. Effects of fertilization on quality of range forage. U. S. Dep. Agr. Misc. Publ. 1147. 57-62 p.

Eckert, R. E., Jr. 1957. Vegetation-soil rela- tionships in some Artemisia types in northern Harney and Lake Counties, Ore. Ph.D. Thesis, Ore. State Univ., Corvallis. 208 p.

Eckert, Richard E., Jr., A. T. Bleak, and Jos. H. Robertson. 1961. Effects of macro- and micronutrients on the yield of crested wheatgrass. J. Range Manage. 14:149-155.

Hull, A. C., Jr. 1963. Fertilization of seeded grasses on mountainous rangelands in northeastern Utah and southeastern Idaho. J. Range Manage. 16:306-310.

Hyder, D. N., and Forrest A. Sneva. 1963. Studies of six grasses seeded on sagebrushbunchgrass range. Agr. Exp. Sta., Ore. State Univ., Corvallis. Tech. Bull. 71.20 p.

Kay, Burgess L., and Raymond A. Evans. 1965. Effects of fertilization on a mixed stand of cheatgrass and intermediate wheatgrass. $\mathbf{J}$. Range Manage. 18:7-11.

Lavin, Fred. 1967. Fall fertilization of intermediate wheatgrass in the southwestern Ponderosa pine zone. J. Range Manage. 20:16-21.

Patterson, J. K., and V. E. Youngman. 1960.
Can fertilizers effectively increase our range land production? J. Range Manage. 13:255-257.

Rumburg, C. B. 1961. Fertilization of wet meadows-A Progress Report. Ore. State Univ., Corvallis. Misc. Paper 116. 31 p.

Sneva, Forrest A., Donald N. Hyder, and C. S. Cooper. 1958. The influence of ammonium nitrate on the growth and yield of crested wheatgrass on the Oregon high desert. Agron. J. 50:40-44.

Sneva, Forrest $\Lambda$., and D. N. Hyder. 1965. Yield, yield-trend, and response to nitrogen of introduced grasses on the Oregon high desert. Spec. Rep. 195. Ore. State Univ., Corvallis. 18 p.

Sneva, Forrest A. 1970. Nitrogen and crested wheatgrass. Squaw Butte Exp. Sta. Mimeo. $6 \mathrm{p}$.

Walker, T. W. 1956. The nitrogen cycle in grassland soils. J. Sci. Food Agr. 7:66-72.

Wullstein, LeRoy H., and C. M. Gilmour. 1964. Gaseous nitrogen losses and range fertilization. J. Range Manage. 17:203.

\section{Vegetative Response to Chemical Control of Broom Snakeweed

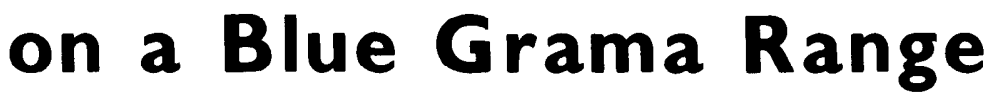

\section{R. W. GESINK, H. P. ALLEY, AND G. A. LEE}

Highlight: All rates of picloram, either alone or in combination with low rates of 2,4-D, effectively controlled broom snakeweed on a blue grama range in southeastern Wyoming. Picloram also eliminated the low amounts of plains pricklypear present among the dense stands of snakeweed. Blue grama was initially injured by the 0.5 and $1 \mathrm{lb} /$ acre rates of picloram, but needle-and-thread was damaged only by the $1 \mathrm{lb} / \mathrm{acre}$ rate. This initial injury to the grasses had a renovating effect upon the range, and, in combination with the elimination of undesirable plants, resulted in notable range improvement as measured 5 years after treatment. The study illustrates how herbicides may be a useful tool for selective manipulation of rangeland vegetation.

Numerous studies concerning chemical control of undesirable plants on native rangeland have been reported over the years. Relatively little information, however, is available regarding the long-term effects of herbicides, particularly as they influence non-target components of the

The authors are a graduate student, professor and extension weed specialist, and assistant professor, Plant Science Division, University of Wyoming at Laramie.

This paper is published with the approval of the Director, Wyoming Agricultural Experiment Station, as Journal Article No. 515.

The authors express their appreciation to Richard Strom, rancher, Laramie, Wyo., for providing a research area, and gratefully acknowledge the valued assistance of $T$. E. Bedell and R. L. Lang, Plant Science Division, Univ. of Wyoming, Laramie.

Manuscript received March 11, 1972. plant community. Laycock and Phillips (1968) have pointed out that the long-term ecological effects must be known if a herbicide is to be adequately evaluated as a method of range improvement. Because of time consuming methods, herbicide treatments are often evaluated in terms of the response of a single species (Hyder, 1971); and usually, only the short-term effects are reported.

The study presented here is an evaluation of the vegetative changes on a blue grama (Bouteloua gracilis [H.B.K.] Lag. ex Steud.) range in southeastern Wyoming, 5 years after the area had been subjected to treatment with herbicides. The treatments were made initially to investigate their effectiveness in the con- 